\title{
Disrupted by violence: children's well-being and families' economic, social, and cultural capital in Ciudad Juarez, Mexico
}

\author{
Alma A. Hernandez ${ }^{1}$ and Sara E. Grineski²
}

Suggested citation Hernandez AA, Grineski SE. Disrupted by violence: children's well-being and families' economic, social, and cultural capital in Ciudad Juarez, Mexico. Rev Panam Salud Publica. 2012;31(5):373-9.

\begin{abstract}
Since 2008, Ciudad Juarez (Chihuahua, Mexico) has been undergoing a wave of violence due to a drug war, making the city a difficult environment in which to raise a family. This study uses qualitative methodology that incorporates 16 in-depth interviews with parents of children ages $0-5$ years and 9 sets of photos from a subset of interviewed parents. The study explores how families' economic, social, and cultural capital has been disrupted by the violence and how it affects children's well-being. Social and economic capital declined significantly because of the violence as families experienced crime, had increased difficulty finding and maintaining employment, and decreased their interactions outside the home. Interviews also suggested that opportunities to gain cultural capital decreased because of this isolation. Understanding the detrimental effects of violence on families' capital can contribute to understanding children's well-being in violence-stricken communities.
\end{abstract}

Key words Child health (public health); family health; safety; violence; Mexico.

Children's well-being is threatened when they do not have a safe environment in which to live and when they do not receive adequate health care, educational enrichment opportunities, and nutrition. This study looks at children's well-being in poor colonias (i.e., neighborhoods) in Ciudad Juarez, a United States-Mexico border city that has been deeply affected by drug-related violence since 2008. This paper uses Bourdieu's (1) theoretical framework on the forms of capital (i.e., economic, social, and cultural) to examine the effect of violence on families' capital and therefore

Department of Sociology, University of New Mexico, Albuquerque, New Mexico, United States of America. Send correspondence to: Alma A. Hernandez, aahernandez4@miners.utep.edu

2 Department of Sociology, University of Texas at El Paso, El Paso, Texas, United States of America. on children's well-being. Bourdieu's (1) work has been used in studies related to children's health and well-being (2-7). Economic capital refers to the money and other material resources that one possesses; social capital involves how one can activate resources through group membership, trust, and support; and cultural capital refers to legitimate knowledge in terms of education, knowledge, and skills (2). While this study focuses on families' capital, Bourdieu suggested that differences in childhood experiences give individuals different economic resources, social connections, and cultural skills, which can affect their lives as adults (7).

A family's lack of economic capital affects a child's well-being even before birth. Children from poor families are at greater risk for poor cognitive, be- havioral, and health outcomes than are wealthier children $(8,9)$. Berger et al. (10) found that 3-year-old children from lower-income families were more likely to lack emotional support and to have low levels of cognitive stimulation than were wealthier children; they were also more likely to have mothers who were stressed, depressed, harsh, and unresponsive. The combination of poverty and exposure to violence can have negative long-term effects on children's wellbeing (11). During periods of increased drug-related violence, which occurred in parts of Latin America in the 1990s, such as Mexico, Colombia, Peru, and Guatemala, poor families experienced higher incidences of crime and unemployment, which disrupted their children's access to food (12-14), and faced greater exposure to severe community violence, 
which was detrimental to their children's well-being and their day-to-day quality of life (13-16).

One way social capital is linked to children's well-being is in helping parents cope with the stresses of poverty (17), as they can access needed resources and social support through their networks. Parents with broader and deeper social networks (i.e., more social capital) experience less stress and tend to lead healthier lives because social ties lessen the negative effects of poverty (18). Contextual factors, such as political unrest and violence, can reduce parents' willingness to establish and maintain social ties (19). Research in Latin America focused on conflicts in Colombia, Peru, and Guatemala has revealed that drug violence restricted parents' access to social capital and eroded established social ties that were based on trust through increased social isolation caused by fear $(12,14,16,20)$.

While cultural capital has not been the focus of much research in relation to health [see Abel et al. (2) and Grineski (3) for exceptions], less parental education (i.e., cultural capital) has been shown to be a predictor of worse children's health (4). Children whose parents have less educational attainment tend to have reduced access to cultural resources, such as checking out books at the library, visiting museums, and attending musical events (4). Violence has been found to negatively affect children's access to cultural resources as families feared public spaces and became isolated, reducing the cultural capital they could gain from attending events and socializing in both Colombia and Guatemala (12-16). Latin American youth lacking social capital in their neighborhoods tended to perform more poorly in school and have a higher probability of dropping out (14), limiting their stock of cultural capital.

This study aims to diminish a gap in the literature related to a lack of knowledge about the effects of armed conflict on children, which is cause for concern (21). The specific objective is to address how the violence is disrupting families' economic, social, and cultural capital and affecting children's well-being.

\section{CONTEXT AND SETTING}

Families living in poverty in underserved colonias along the United StatesMexico border face a number of chal- lenges (e.g., reduced access to potable water and electricity, unpaved streets, and little police and fire protection) that profoundly affect the children living there (22). Ciudad Juarez, the setting for this study, is located along the Mexican border with the United States and has an estimated population of 1.3 million (23). Since 2008, the city has suffered from the local impacts of a worldwide recession and a wave of drug-related violence. The city had attracted rural migrants because of regional employment opportunities (e.g., in the maquiladoras or final assembly plants) for decades, although migration has slowed because of the economic recession and violence. Factors such as a shortage of jobs in the interior of Mexico and the increased demand for unskilled labor in the border region have pushed residents to seek employment in maquiladoras in border cities (24). Although migrants come to Juarez to improve their economic status, many struggle to meet the needs of their family, given the low wages maquiladoras tend to pay. Most maquiladora workers take home less than 55.55 pesos (approximately US\$ 5.00) a day, which is only $30 \%$ of what a family of four requires to meet its basic needs (25).

In terms of the drug-related violence, according to New Mexico State University researcher Molly Molloy, more than 10000 killings have been reported in Ciudad Juarez since 2008 (26). In 2010, the death count totaled 3622 (26). With 322 drug-related killings in August 2010 alone (27), which is as many as 22 per day, Ciudad Juarez is one of the most murderous cities in the world (28). Some of the everyday problems for parents living in Ciudad Juarez, apart from the murders, are business extortions, shootings, gruesomely violent imagery (e.g., public displays of dead human bodies and body parts), car theft, and dangerous traffic conditions as criminals evade police and crime scenes. The violence also affects Juarez economically, not only by dramatically reducing tourism from the United States, which used to contribute to the small business economy, but also because extortions have forced many businesses to close, therefore reducing the employment opportunities for Juarenses. An estimated 10000 small businesses have closed or moved across the border to Texas since the violence began in 2008. Recovery of jobs lost during the recession is slow compared with the State of Chihuahua as a whole (29).
The ongoing drug war has left more than 10000 children in Mexico orphaned and more than 40000 relatives of victims affected by the violence (30). Parents feel pressure to keep their children inside the home, and daily activities such as grocery shopping and even traveling to school have become a challenge because of shootouts on the streets (31). With the current rise in crime and violence in Mexico, and specifically in Ciudad Juarez, parents are experiencing high levels of distress and concern about the safety of themselves and their children (32).

\section{DATA AND METHODS}

This study was conducted in collaboration with Gente a favor de gente (People helping people), a Juarez community group. The collaboration provided access to conduct this study but limited the range of participants to those living in the two poor neighborhoods that Gente serves. Drawing from a sample of 300 families enrolled in a child development intervention during 2009-2010 (31), indepth interviews were conducted with 16 parents (14 mothers, 2 fathers) in May and June of 2010 (contact authors for interview schedule) and photo interviews were conducted with 9 of the mothers. Institutional Review Board approval was granted by The University of Texas at El Paso for use of the intervention data and for conducting in-depth and photo interviews; participants provided written consent at each stage of the project.

The first 16 parents were randomly selected for interviews, based on information provided in the intervention, from two subgroups of families with more than one child: those with and those without a caretaker employed in a maquiladora. Maquiladora employment was considered because they are the primary formal employers in the city. Parents were interviewed in their homes (range 49 minutes to 2 hours and 3 minutes) by Vicky Ramos, a community leader with Gente who has research training; each interviewee received a \$20 gift card. The interviews were conducted, digitally recorded, transcribed, and analyzed in Spanish (by the first author) using $\mathrm{N}^{*}$ VIVO qualitative analysis software; as a native speaker of Spanish and English, she also translated the quotes presented in this paper.

Photo interviews with nine of the mothers were then used. Photo interviews involved the mothers taking pho- 
TABLE 1. Descriptive information for participating parents in Ciudad Juarez, 2010

\begin{tabular}{|c|c|c|c|c|c|c|c|c|c|}
\hline Pseudonym & Education & Mother's job & Father's job & $\begin{array}{c}\text { Monthly } \\
\text { income, } \\
\text { U.S. dollars }{ }^{a}\end{array}$ & $\begin{array}{l}\text { Marital } \\
\text { status }\end{array}$ & $\begin{array}{l}\text { Number of } \\
\text { children }\end{array}$ & Time in Juarez & $\begin{array}{c}\text { Experienced } \\
\text { violence } \\
\text { or crime }\end{array}$ & $\begin{array}{c}\text { Participated } \\
\text { in photo } \\
\text { interview }\end{array}$ \\
\hline Maria & 6th grade & Stay at home & Construction & 171 & Married & 3 & Lifetime & Yes & No \\
\hline Josefina & No answer & Stay at home & Construction & 240 & Married & 3 & Lifetime & Yes & Yes \\
\hline Linda & Technical & Stay at home & Maquila & 205 & Married & 4 & Lifetime & Yes & Yes \\
\hline Jose & 6 th grade & Maquila & Vends food & 195 & Married & 2 & $6-10$ years & Yes & Yes \\
\hline Luz & 8 th grade & Stay at home & Maquila & 322 & Married & 3 & $1-5$ years & No & Yes \\
\hline Lucero & 8 th grade & Maquila & $\mathrm{N} / \mathrm{A}$ & 222 & Single & 2 & Lifetime & No & Yes \\
\hline Monica & 9th grade & Stay at home & Maquila & 171 & Married & 3 & Lifetime & No & No \\
\hline Laura & 6 th grade & Stay at home & Maquila & 279 & Married & 2 & $6-10$ years & No & Yes \\
\hline Juan & 10th grade & Stay at home & Maquila & 197 & Married & 2 & $6-10$ years & Yes & No \\
\hline Ana & 9th grade & Vends from home & Grocery store & 171 & Married & 1 & $6-10$ years & Yes & No \\
\hline Lupe & 1st grade & Maquila & $\mathrm{N} / \mathrm{A}$ & 260 & Single & 5 & $>20$ years & No & No \\
\hline Carla & 6 th grade & Vends from home & Car lot & 171 & Married & 3 & $11-20$ years & Yes & No \\
\hline Martha & 8 th grade & Stay at home & Mechanic & $\mathrm{N} / \mathrm{A}$ & Married & 2 & $>20$ years & Yes & No \\
\hline Consuelo & 6 th grade & Sells shoes & Maquila & 103 & Married & 3 & Lifetime & Yes & Yes \\
\hline Rosa & 10th grade & Stay at home & Informal & 240 & Married & 2 & Lifetime & Yes & Yes \\
\hline Teresa & 3rd grade & Stay at home & Informal & 376 & Married & 2 & $>20$ years & Yes & Yes \\
\hline
\end{tabular}

Note: N/A: not available.

a Average currency exchange rate in 2010 was 13.15 Mexican pesos per U.S. dollar (35).

tos that represented their everyday lives as parents, focusing on factors that relate to children's well-being. After photos were taken, Vicky Ramos asked each participant to describe at least six of her photos (each took up to 54 photos). Descriptions were gathered by using a worksheet adapted from De Heer et al. (33) (contact authors for photo interview schedule). Each of the nine mothers received $\$ 30$ in gift cards and a picture album of the photos. Participants were asked on two occasions for permission to use each photo, with the option of hiding the faces (as per Institutional Review Board requirements). Transcripts and captions were coded by the first author using thematic coding. Drawing from the theoretical framework and in line with the study objectives, she first identified how economic, social, and cultural capital affected children's wellbeing (three nodes); within those nodes, she subcoded for the theme: impacts of violence (34). Characteristics of participating parents (by pseudonym) are presented in Table 1.

\section{RESULTS}

\section{How is the violence disrupting families' economic capital and affecting children's well-being?}

Employment was an important source of economic capital (i.e., money and assets) that influenced children's wellbeing. All parents interviewed reported a low household income: mean income of 1354 pesos a month (approximately \$103 in U.S. dollars, calculated at an average currency exchange rate of 13.15 pesos per dollar (35) [range 1350 to 4950 pesos (\$102.66 to \$376 in U.S. dollars) a month]. Most parents attributed their low incomes and employment struggles to the violence and the recession; a number of them reported unstable work hours, as their employers sent them home early because of a lack of demand for labor, influenced by the outmigration of up to $23 \%$ of Juarez households (36) and business closures. A pervasive theme was parents experiencing nearly constant worry about their children's well-being related to their poverty, and many of them expressed that they struggled to provide their children with day-to-day needs during these tenuous times. This situation negatively affected the children's well-being; for example, parents were not able to provide their children with adequate nutrition (Figure 1).

The drug violence seemed to affect the mother's employment options more than the father's. Parents thought it was important for the mother to stay home and protect the children because of the high crime rates. The fear of leaving the children to go to work contributed to mothers' decisions not to work (No. $=10)$. Daycare could hypothetically serve as a facilitator for working mothers, allowing them to earn economic capital while keeping their children safe. However, all participants expressed a lack of trust in daycare services because of drug-related violence and no one was using them at the time of the interview. Given the violence and the rise in extortion of businesses (including daycare businesses), which often have resulted in killings because the businesses did not pay quotas demanded by cartels, parents communicated that they were not comfortable leaving their children home alone or in the care of nonfamily members, such as daycare providers. This fear is rooted in the reality that businesses, regardless of the presence of children, have been extorted and have become victims of violence during the current drug war in Juarez. Thus, mothers' opportunities for employment (and families' economic capital) are negatively affected.

For many families, the rise in crime has directly affected their economic capital (Figure 1), which affects the children's well-being; parents are already scraping by and when items are stolen they have to spend extra money to replace them or sometimes have to do without them. When one family's home gas tank was stolen, the children had to go without warm water and heat until the family could afford to replace the tank. The photo in Figure 1 was taken by Teresa to show the abandoned homes in her neighborhood. The pictured home has been robbed of everything of value, illustrating that when this type of robbery happens, it directly affects the families' economic capital and the children's well-being. 
FIGURE 1. How violence affects economic capital and children's well-being

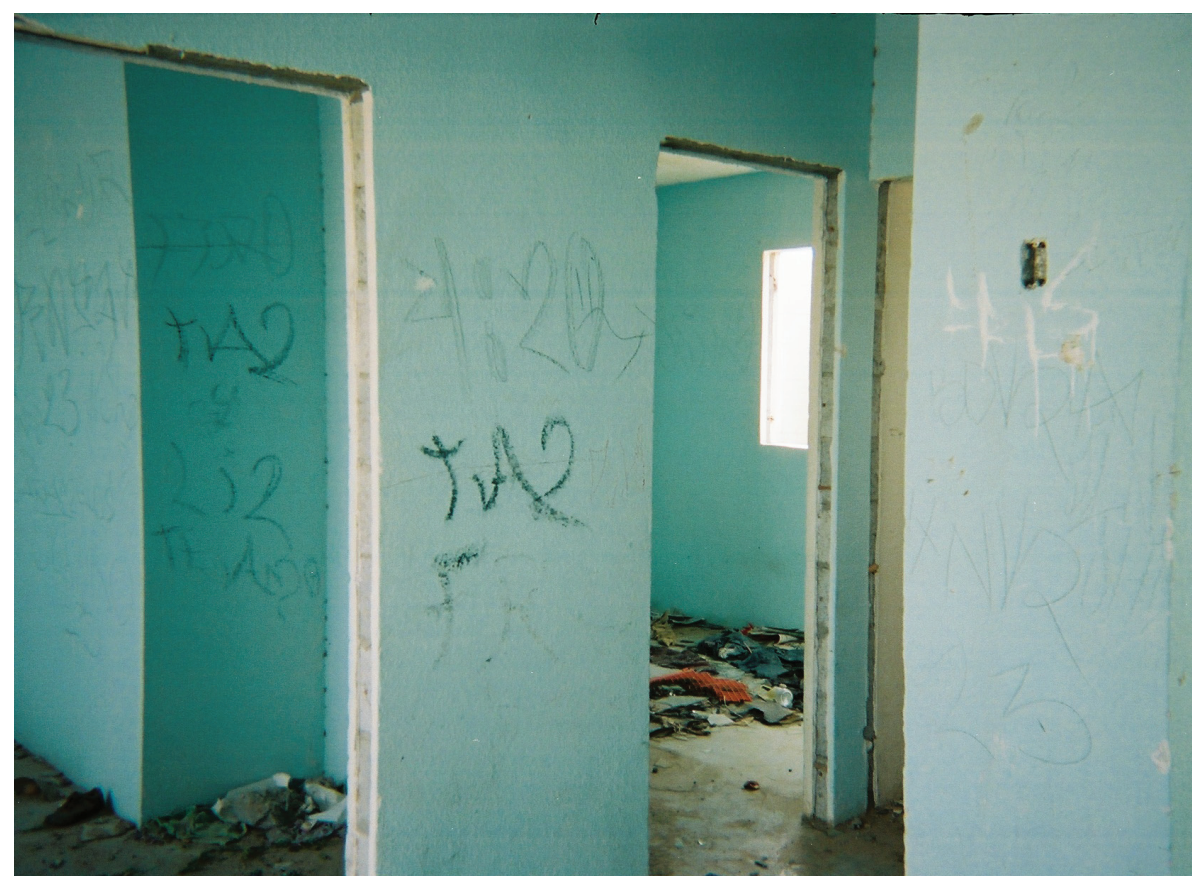

Representative quote: "Meses atrás estábamos bien amolados pero yo también pues no me podía forzar a decirles nomás vamos a comer puros frijoles y huevito." ("Months ago we were doing really bad and I could not force myself to tell them [my children] we are only going to eat beans and eggs.")-Jose. Parent's photo caption: "Esta fotografía la tome para que conocieras el fraccionamiento y la cantidad de casas solas y en las condiciones que se encuentran. Así como la falta de espacios para que los niños jueguen fuera de las viviendas, y si salen y aprovechan el espacio de las casas solas y lo peligroso que esto es con la inseguridad que hay en la ciudad." "The photo was taken so that you [the researcher/audience] know the neighborhood and the number of abandoned homes and under the conditions in which they are found. Just like there is lack of space for children to play outside the house, they can't go out and take advantage of the space of the abandoned houses [because of] how dangerous it is, along with the insecurity in the city.")-Teresa.

\section{How is the violence disrupting families' social capital and affecting children's well-being?}

Social capital was disrupted by the violence. Social capital included family members (counting older children) and to a much lesser degree friends and neighbors and Gente, the community group serving the area. For all 16 participants, the violence was a deterrent in being able to fully utilize the resources provided by familial networks because people were forced to limit the time they spent with family and friends. Families who lived across town did not want to commute through the dangerous city to visit relatives. Leaving after dark was out of the question as parents feared they might be in danger while driving to and from a relative's home. Therefore, violence directly reduced the opportunities for children and parents to develop and utilize social capital (Figure 2).

Most parents $($ No. $=14)$ mentioned that they did not have friends (including neighbors) to support them. This could be due to the distrust caused by violence. For instance, when asked how her neighbors assist her with her children, Linda responded: "Pues la verdad, si también porque pues no tengo vecinos. Casi ya ni salen afuera ni a caminar, ni nada." ("Well the truth is, well also, because I do not have neighbors. They don't even go outside or not even to walk, or anything.") Her neighbors are afraid to go outside or socialize with someone who could be targeted by the drug cartel. Consuelo provides another example; she and her children witnessed her brother being killed when he was caught in crossfire in front of her home. Not only was her family affected by the loss of her brother (a previous source of social capital) but the relationship her family had with the neighbors was also negatively affected. Consuelo experienced stigma because her neighbors believed her brother was involved in the drug business. The fact that her neighbors view her as somehow involved in the violence reduced their social capital, further isolating them. For Consuelo, it was difficult to approach her neighbors for assistance, such as asking them to babysit or to borrow something. This also narrowed her children's opportunities to socialize with neighborhood children, which affected their well-being through stigma and the isolation that the violence imposed on them.

\section{How is the violence disrupting families' cultural capital and affecting children's well-being?}

Educational opportunities are a key source of cultural capital for children (2). The challenges of poverty are exacerbated by the violent situation in Juarez as parents make less money and have fewer contacts with friends and family. This likely contributes to cultural capital deficits for children, as it may reduce their access to education in the future. Half of the parents discussed how they were unable to stay in school past their middle school years because they needed to work. No parent had achieved education beyond high school. This is of concern because parents generally attributed their lack of educational opportunities to poverty, which was increasingly affecting their children at the time of the interview.

Apart from the formal educational sector, children are also less able to gain cultural capital through informal experiences. Parents reported that children spend most of their time outside of school isolated in the home-not interacting with cousins or young neighbors or playing sports in parks-because of safety concerns. Therefore, they have fewer opportunities to learn practical skills (e.g., sharing with others, working together in teams, and "street smarts"), which would serve as cultural capital in their lives. At the same time, the limited nature of the time spent outside the home limits their abilities to attend events (e.g., free concerts, soccer games, school programs), where they would gain cultural capital. All 16 families described having to isolate their children because the environment is too dangerous for them to participate in what would be normal activities for children (Figure 3).

\section{DISCUSSION}

This study revealed that parents' access to economic, social, and cultural 
FIGURE 2. How violence affects social capital and children's well-being

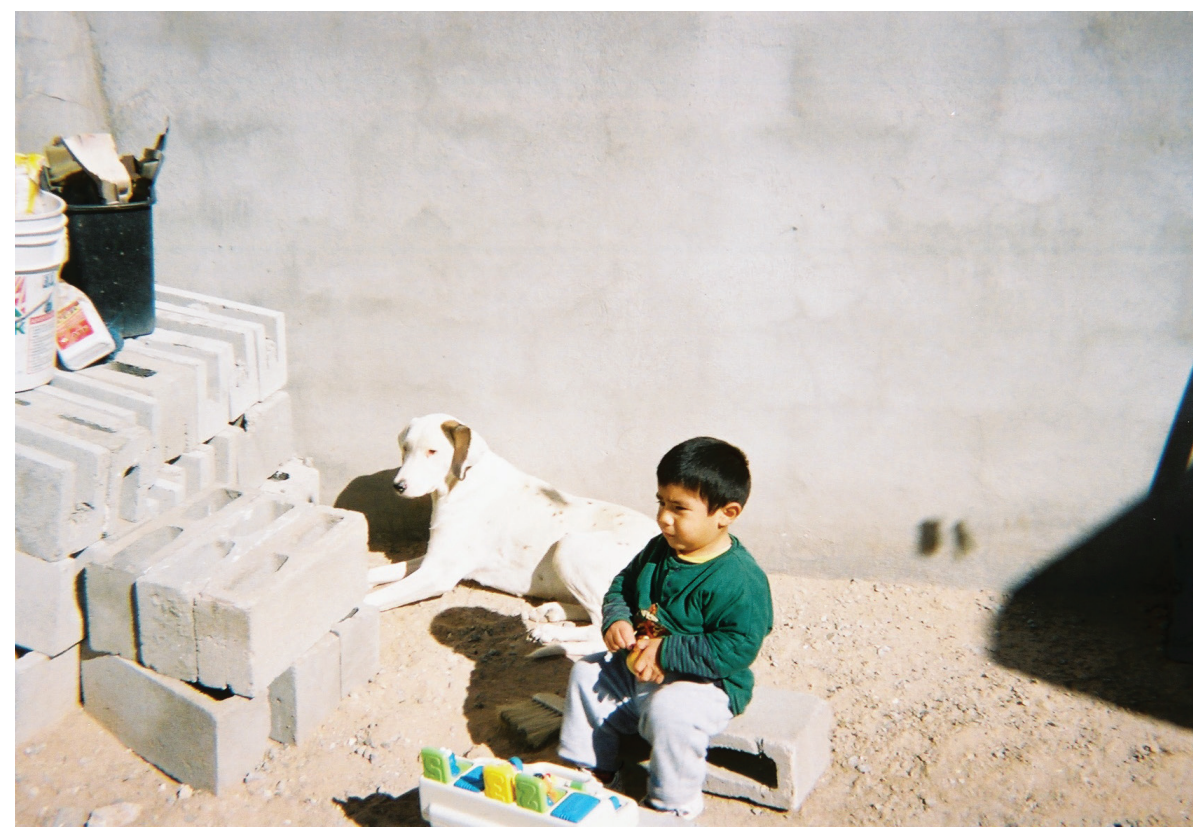

Representative quote: "Casi no tenemos amigos y los que teníamos que éramos muy cercanos se fueron." ("We hardly have any friends, and the ones that we were really close to left.")-Carla. Parent's photo caption: "Los niños necesitan más espacio y más compañía para jugar, pero preferimos que se desenvuelva un poco solitario pero más seguro en su casa por eso le tenemos su mascota para que juegue, sabemos que no es lo mismo, pero no hay seguridad afuera." ("Children need more space and more company to play with, but we prefer that he grows up a little lonely, but safer at his home, so that's why he has a pet to play with, we know that is not the same, but there is no security outside.")-Teresa.

\section{FIGURE 3. How violence affects cultural capital and children's well-being}

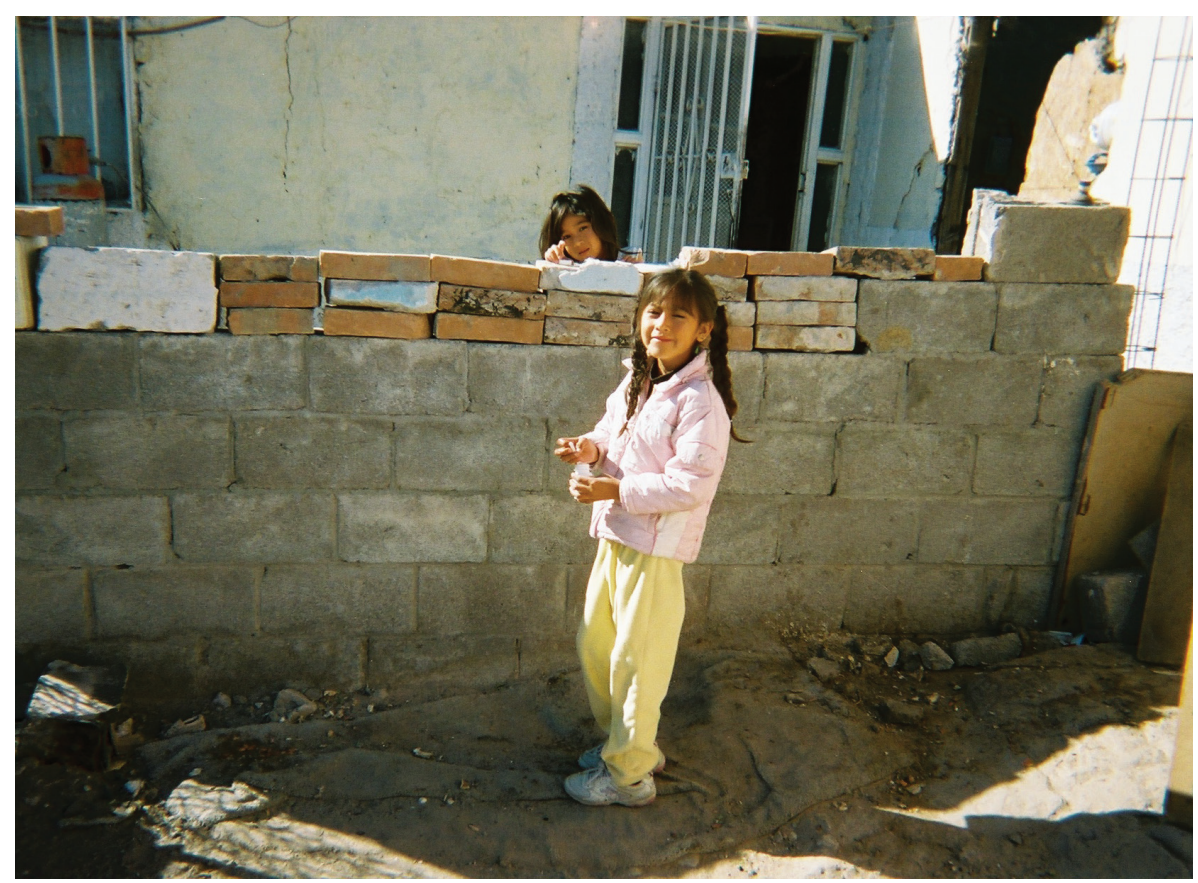

Representative quote: "Se les prohíben uno mucho y en muchas cosas, como no andar solos, de que no anden en la tienda solos, o vayan al parque con sus amigos, y antes yo los dejaba irse con confianza pero ahora no." ("They [children] are prohibited from a lot, and many things, like not hanging around alone, that they don't go to the store alone, or go to the park with their friends, and in the past I would be confident to allow them to go but not anymore.")-Josefina. Parent's photo caption: "Me parece importante que conviva con otras personas porque a veces se sienten solas porque en realidad no salimos mucho." ("I think it is important that they socialize with other people because sometimes they feel lonely because in reality we do not go out often.")-Laura. capital is negatively affected by drug violence as families were increasingly isolated from employment opportunities, interactions with others, and community involvement. The challenges of poverty were heightened by violence. All parents were poor with unstable employment due to the recent economic recession, and the current drug war in addition to a rise in theft contributed to their low incomes. Something similar was found in Colombia, Peru, and Guatemala in relation to drug violence $(12,14)$. In accordance with Berger et al. (10) and Lareau (7), Juarez parents constantly worried about their children's well-being related to their poverty. However, this worry seemed more extreme because of the violent environment.

The limits that violence imposes on social networks have caused parents to isolate their children due to fear that they might become victims of violence through their associations or due to random acts of violence in the streets (12-16). Apart from the mother, interviews revealed that immediate family members residing in the home (father, older siblings) were the only other social capital for most families. This finding differed from those of Øyen (18) and Lareau (7), who both recognized the importance of extended family members as social capital for poor families in the United States. Among participating families, benefits from kinship ties pertained primarily to immediate family members because most parents lived away from their extended family or were hesitant to visit relatives in Juarez because of the violence. The isolation of families within their homes, which was clearly evident from the interviews, has not only affected their social capital, it has also severely reduced their access to cultural capital. If the violence continues, it is likely that cultural capital will continue to decline; the isolation (month after month and year after year) can have negative effects on children's well-being as they are not gaining the benefits of interacting with others, and children may be forced to drop out of school because of concerns for safety and economic needs as noted by Ayres (14). Given that the marginalized and semiemployed youth of Juarez have become readily employable for cartels, gangs, and kidnapping/ extortion rings (37), this situation is especially troubling. 


\section{Conclusion}

This study was limited to 16 interviews and no follow-ups in order to minimize risks to the interviewer because of ongoing and escalating violence. More interviews would have allowed for better generalizability and evidence of emergent findings. While the collaboration with Gente was essential to the success of the project, it meant that the sample was relatively homogeneous in terms of income and geographic location, even though it did vary in terms of family composition, length of residence in Juarez, and employment, among other attributes. Future research should interview families of various social classes and geographic areas to truly understand the impacts of drug-related violence on children's well-being in a variety of social contexts.
Although the data reflect the situation of families residing in Juarez, it is likely that the same case exists for many families across Mexico as findings were similar to those in studies conducted in Colombia, Peru, and Guatemala (12-14, 16). In terms of policy recommendations, the findings lead us to suggest:

- Efforts to reduce violence because of its harmful effects on families and children;

- Programs that promote stable working hours for employees and offer benefits that improve livelihoodsfor instance, providing workers with safe daycare centers; and

- Programs and policies, including those that create safe community spaces, reduce children's isolation, protect youth from becoming victims of violence, and keep them from becoming part of the criminal activity-

\section{REFERENCES}

1. Bourdieu P. The forms of capital. In: Richardson JG, ed. Handbook of theory and research for the sociology of education. New York: Greenwood Press; 1986. Pp. 241-57.

2. Abel T, Fuhr DC, Bisegger C, Rau SA, The European Kidscreen Group. Money is not enough: exploring the impact of social and cultural resources on youth health. Scand J Public Health. 2011;39(6):57-61.

3. Grineski S. Why parents cross for children's healthcare: transnational cultural capital in the United States-Mexico border region. Social Theory Health. 2011;9:256-74.

4. Dumais S. Cultural capital, gender, and school success: the role of habitus. Sociol Educ. 2002; 75(1):44-68.

5. Lareau A. Social class differences in familyschool relationships: the importance of cultural capital. Sociol Educ. 1987;60(2):73-85.

6. Lareau A. Invisible inequality: social class and childrearing in black families and white families. Am Sociol Rev. 2002;67(5):747-76.

7. Lareau A. Unequal childhoods: class, race and family life. Berkeley and Los Angeles, CA: University of California Press; 2003.

8. Yudkin S, Yudkin G. Poverty and child development. Dev Med Child Neurol. 2010;10(5): 569-79.

9. Abel T. Cultural capital in health promotion. In: McQueen DV, Kickbush I, eds. Health and modernity: the role of theory in health promotion. New York: Springer; 2007. Pp. 43-73.

10. Berger L, Paxson C, Waldfogel J. Income and child development. Child Youth Serv Rev. 2009;31:978-89.

11. Bell CC, Jenkins EJ. Community violence and children on Chicago's southside. Psychiatry. 1993;56:46-54.

12. Jimeno M. Violence and social life in Colombia. Crit Anthropol. 2001;21(3):221-46. tions of violence and exclusion in Colombia. Washington, DC: World Bank; 2000.

14. Ayres, RL. Crime and violence as development issues in Latin America. Washington, DC: World Bank; 1998.

15. Salzinger S, Feldman RS, Stockhammer T, Hood J. An ecological framework for understanding risk for exposure to community violence and the effects of exposure on children and adolescents. Aggress Violent Behav. 2002;7(5):423-451.

16. Moser C, Mcllwaine C. Encounters with violence in Latin America: urban poor perceptions from Columbia and Guatemala. New York: Taylor and Francis; 2004.

17. McCulloch A, Heather EJ. Child development and family resources: evidence from the second generation of the 1958 British birth cohort. J Popul Econ. 2000;15(2):283-304.

18. Øyen E. Social capital formation as a poverty reducing strategy? In: Kazancigil A, Øyen E, eds. Social capital formation in poverty reduction-which role for the civil society organizations and the state: proceedings of United Nations Educational, Scientific and Cultural Organization's Management of Social Transformations Programme and the International Social Science Council's Comparative Research Programme on Poverty Symposium; 200028 June; Geneva. Paris: Social and Human Sciences Sector of UNESCO; 2002. Pp. 11-4.

19. Kotchick BA, Forehand R. Putting parenting in perspective: a discussion of the socialcontextual factors that shape parenting practices. J Child Fam Stud. 2002;11(3):255-69.

20. Mcllwaine C, Moser C. Violence and social capital in urban poor communities: perspectives from Colombia and Guatemala. J Int Dev. 2001;13(7):965-84.
13. Moser C, Mcllwaine C. Urban poor percep- for example, after-school programs can facilitate children's development of supportive social networks and requisite cultural skills, which are more difficult to develop and maintain in violent contexts $(14,16)$.

Acknowledgments. This project was supported by grant P20MD002287 from the National Institutes of Health (NIH), National Center on Minority Health and Health Disparities (NCMHD) through the Hispanic Health Disparities Research Center (HHDRC). The content is the responsibility of the authors and does not necessarily represent the official views of the NIH, NCMHD, or HHDRC. Contributions to this project from Carlos Vasquez, Vicky Ramos, and the parents who participated as well as the psychologists and educators who volunteered their services are gratefully acknowledged.
21. Pedersen J, Sommerfelt T. Studying children in armed conflict: data production, social indicators and analysis. Soc Indic Res. 2007;84(3): 251-69.

22. Heyman J. Environmental issues at the USMexico border and the unequal territorialization of value. In: Hornberg A, McNeill JR, Martinez-Alier J, eds. Rethinking environmental history: world-system history and global environmental change. Lanham, MD: Altamira Press; 2007. Pp. 327-41.

23. Ayala DM. Censo de población y vivienda; 2010. Available from: http://vectoreconomico. com.mx/files/pdfs/r13122010.pdf Accessed 5 July 2011

24. Anderson JB. Effects of increased trade and investment on human development in the US and Mexican border communities. J Dev Areas. 2010;43(2):341-62.

25. Ramirez R. Maquiladora workers can't meet basic needs on plant wages. FronteraNorteSur: U.S.-México Border News. Las Cruces: New Mexico State University; 2001.

26. Frontera Listerve. New Mexico State University Library. Available from: http://groups. google.com/group/frontera-list?hl=en Accessed 29 January 2012.

27. Licón AG. Juárez violence persists: August deadliest month with 322 killed. El Paso Times 2010. September 1. Available from: http: / / www.elpasotimes.com/ci_1595 6844?IADID=Search-www.elpaso times.comwww.elpasotimes.com Accessed 5 September 2010.

28. Chung A. Ciudad Juárez, México: The world's most dangerous place? The Toronto Star 2010. May 21. Available from: http://www.thestar. $\mathrm{com} /$ news/world/article/812757_ciudadjuarez-mexico-the-world-s-most-dangerousplace Accessed 9 September 2010. 
29. Kolenc V. Maquilas dodge the violence: Juárez plants hurt more by recession than drug violence. El Paso Times 2010. March 7. Available from: http://www.elpasotimes. com/ci_14526631?IADID=Search-www.el pasotimes.com-www.elpasotimes.com Accessed 14 September 2010.

30. Paterson K. Solidarity with a besieged sister city. FronteraNorteSur: U.S.-México Border News. Las Cruces: New Mexico State University; 2010.

31. Hernandez, AA. Gente a favor de gentepeople helping people: assessing a child development intervention in colonias in Ciudad Juárez, México. Child Youth Environ. 2011; 21(2):184-94.
32. Kellner T, Pipitone F. Inside México's drug war. World Policy J. 2010;27(1):29-37.

33. De Heer H, Moya EM, Lacson R, Sheldin MG. Voices and images. Tuberculosis photovoice in a binational setting. Cases Public Health Commun Marketing. 2008;2:55-86.

34. Boyatzis RE. Transforming qualitative information: thematic analysis and code development. Thousand Oaks, CA: Sage; 1998. Pp. 29-30.

35. Internal Revenue Service. Yearly average currency exchange rates. Available from: http:/ /www.irs.gov/businesses/small/ international $/$ article $/ 0$, id $=206089,00 . \mathrm{html}$ Accessed 27 January 2012.

36. Stevenson M. 230,000 displaced by Mexico's drug war. El Paso Times 2011. March 26.
Available from: http://www.elpasotimes. com/ci_17700120?IADID=Search-www.el pasotimes.com- Accessed 21 May 2011.

37. Campbell, $\mathrm{H}$. No end in sight: violence in Ciudad Juárez. NACLA Report on the Americas. 2011;May-June:19-22.

Manuscript received on 29 July 2011. Revised version accepted for publication on 2 February 2012.

RESUMEN Desde el 2008, Ciudad Juárez (Chihuahua, México) ha experimentado una ola de violencia debida a una guerra entre narcotraficantes, que convirtió a la ciudad en un entorno difícil para criar una familia. En este estudio se usó una metodología cualitativa que comprendió 16 entrevistas exhaustivas con padres de niños de 0 a 5 años y 9 grupos de fotos de un subconjunto de padres entrevistados. El estudio explora cómo el capital económico, social y cultural de las familias ha sido perturbado por la violencia y cómo se ve afectado el bienestar de los niños. El capital social y económico ha disminuido significativamente a causa de la violencia debido a que las familias experimentaron la criminalidad, tuvieron dificultades crecientes para encontrar y conservar el empleo y redujeron sus interacciones fuera del hogar. Las entrevistas también indicaron que las oportunidades de mejorar el capital cultural disminuyeron debido a este aislamiento. La comprensión de los efectos perjudiciales de la violencia sobre el capital familiar puede contribuir a comprender el bienestar de los niños en las comunidades golpeadas por la violencia.

Palabras clave Salud del niño; salud de la familia; seguridad; violencia; México. 